\title{
AL-IQTISHADIYAH
}

Jurnal Ekonomi Syariah dan Hukum Ekonomi Syariah

E-ISSN: 2621-0274; P-ISSN: 2442-2282

Volume 5, Nomor 1, Juni 2019

\section{PENERAPAN MODEL PENGASUHAN BERSAMA (SHARED PARENTING) DALAM PENYELESAIAN SENGKETA HAK ASUH ANAK}

\section{Natsir Asnawi}

Fakultas Studi Islam, Universitas Islam Kalimantan Muhammad Arsyad al-Banjari, Indonesia. E-mail: alamatemail@uniska-bjm.ac.id

\section{ARTICLE INFO}

Kata Kunci:

Pengasuhan Anak;

Pengasuhan Bersama

\section{ABSTRAK}

Hukum hak asuh anak di Indonesia, dari sisi normatif dan praktik, secara umum masih menerapkan model pengasuhan terpisah atau pengasuhan oleh salah seorang orangtua anak (split parenting, split custody). Patronase penentuan hak asuh dalam penyelesaian sengketa hak asuh anak ada dua. Pertama, patronase normatif dengan mengacu pada ketentuan Pasal 105 Kompilasi Hukum Islam. Kedua, patronase kepentingan terbaik anak berdasar Yurisprudensi Mahkamah Agung. Pengasuhan bersama (shared parenting) merupakan gagasan yang ingin menengahi perbedaan kedua model Gagasan ini ingin menengahi perbedaan kedua model dan patron tersebut serta menawarkan suatu konsep pengasuhan yang tidak hanya berfokus pada perwujudan kepentingan terbaik si anak, namun juga mengupayakan peran maksimal kedua orangtua dalam mengasuh anak-anaknya.

\section{Pendahuluan}

Hak asuh anak merupakan salah satu cabang dari hukum keluarga yang mendapat perhatian cukup masif dari pegiat hukum keluarga. Ini dikarenakan arketip hak asuh anak berkenaan langsung dengan hak-hak dasar anak untuk mendapatkan pengasuhan dan pemenuhan hak-hak lahiriah si anak.

Penentuan hak asuh anak dalam praktiknya sering menemui persinggungan antara penerapan pengasuhan anak secara normatif berdasar Pasal 105 Kompilasi Hukum Islam yang menentukan bahwa pengasuhan anak usia di bawah 12 tahun ditetapkan kepada ibu kandungnya vis a vis dengan norma pengasuhan anak berdasar kepentingan terbaik anak yang dilegitimasi berdasar Yurisprudensi Mahkamah Agung. Persinggungan dua norma tersebut membawa akibat praksis penentuan hak asuh anak dalam putusan-putusan sengketa hak asuh anak di Pengadilan cukup beragam.

Perbedaan cara pandang terhadap penentuan hak asuh anak lebih disebabkan pada pilihan atau diskresi Hakim dalam menentukan patron mana yang ingin dikedepankan dalam memutus sengketa hak asuh anak. Penekanan berlebihan terhadap aspek normatif menyebabkan hak-hak dan kepentingan terbaik anak dapat terabaikan. Sebaliknya, penekanan pada aspek mengupayakan kepentingan terbaik 
anak memerlukan pembuktian yang lebih kompleks, termasuk namun tidak terbatas pada penelusuran rekam jejak kedua orangtua si anak, dinamika relasi hubungan orangtua dan anak, serta lain-lain keadaan yang perlu diketahui untuk memastikan tujuan pengasuhan anak tersebut tercapai.

Pada kedua model maupun patron penentuan hak asuh anak tersebut, muncul gagasan penerapan pengasuhan bersama atau shared parenting (sering pula disebut dengan joint custody). Gagasan ini ingin menengahi perbedaan kedua model dan patron tersebut serta menawarkan suatu konsep pengasuhan yang tidak hanya berfokus pada perwujudan kepentingan terbaik si anak, namun juga mengupayakan peran maksimal kedua orangtua dalam mengasuh anak-anaknya.

Risalah ini mencoba mengelaborasi konsepsi pengasuhan bersama dengan berupaya mengemukakan perkembangan-perkembangan pemikiran mengenai pengasuhan anak. Analisis diperkuat dengan sistensi norma pengasuhan dalam Kompilasi Hukum Islam serta norma-norma terbaru yang berkembang dalam praksis penegakan hukum hak asuh anak di Indonesia (yurisprudensi).

\section{Metode Penelitian}

\subsection{Jenis Penelitian}

Penelitian ini merupakan penelitian penelitian normatif (normative study). Penelitian normatif adalah suatu penelitian hukum terhadap aturan-aturan, norma, dan asasasas hukum, termasuk pula doktrin-doktrin hukum yang berkembang dan relevan dengan tema penelitian). Penelitian normatif menurut Soerjono Soekanto diarahkan pada penelitian yang menarik asas-asas hukum, sistematika hukum, sinkronisasi peraturan perundang-undangan, perbandingan hukum, dan sejarah hukum ${ }^{1}$.

\subsection{Pendekatan}

Pendekatan yang digunakan dalam penelitian ini adalah pendekatan perundangundangan (statute approach) dan pendekatan konseptual (conceptual approach). Pendekatan perundang-undangan adalah pendekatan penelitian yang analisisnya berbasis pada asas, norma, dan aturan-aturan perundang-undangan, termasuk pula norma dalam putusan-putusan yang menjadi yurisprudensi tetap Mahkamah Agung. Sementara pendekatan konseptual adalah pendekatan yang ingin membangun suatu konsep secara komprehensif mengenai hal yang diteliti. Konsep yang ingin dibangun dapat merupakan penyempurnaan konsep yang telah ada dan dapat pula merupakan konsep baru yang sama sekali belum pernah ada sebelumnya. Kedua pendekatan ini akan menjadi patron dalam merumuskan analisis terhadap pokok permasalahan penelitian ini

\footnotetext{
${ }^{1}$ Soerjono Soekanto, 2007, Pengantar Penelitian Hukum, Jakarta: UI Press, hlm. 51.
} 


\subsection{Sumber data}

Sumber data penelitian hukum disebut juga dengan sumber-sumber penelitian hukum. Sumber-sumber penelitian hukum menurut Peter Mahmud Marzuki terdiri atas dua, yaitu sumber atau bahan hukum primer dan sumber atau bahan hukum sekunder. Bahan hukum primer adalah bahan hukum berupa perundang-undangan dan putusan hakim. Sementara itu, bahan hukum sekunder adalah bahan hukum berupa publikasi-publikasi mengenai hukum yang tidak termasuk dalam dokumen resmi Negara ${ }^{2}$. Publikasi-publikasi hukum banyak mengandung doktrin-doktrin hukum yang berguna dalam tataran akademik maupun praksis hukum.

Bahan hukum primer penelitian ini adalah perundang-undangan dan putusan Pengadilan yang relevan dengan tema penelitian. Perundang-undangan yang menjadi bahan utama penelitian adalah Kitab Undang-Undang Hukum Perdata (burgerlijk wetboek) selain tentu juga beberapa perundangan lain yang dianggap relevan dengan tema penelitian. Adapun putusan yang menjadi bahan penelitian adalah putusan pengadilan mengenai perjanjian yang telah menjadi yurisprudensi tetap. Sementara itu, bahan hukum sekunder dalam penelitian ini adalah buku maupun jurnal ilmiah baik yang berbahasa Indonesia maupun berbahasa asing yang tema utama bahasannya terkait dengan hukum perjanjian.

\subsection{Pengumpulan data}

Teknik pengumpulan data dalam penelitian ini adalah inventarisasi perundangundangan yang relevan, yurisprudensi, buku-buku, jurnal, dan publikasi ilmiah lain yang membahas mengenai asas kebebasan berkontrak dan keseimbangan kedudukan para pihak dalam perjanjian (asas keadilan). Keseluruhan data yang diperoleh tersebut akan dianalisis melalui pembacaan dan penelaahaan data secara sistemik, yaitu membaca data secara keseluruhan dan memperbandingkannya satu sama lain.

\subsection{Analisis data}

Analisis terhadap data-data yang diperoleh dalam penelitian ini bersifat preskiptif. Preskriptif memuat hasil analisis yang menguraikan sisi normatif dari suatu pengaturan dalam perundang-undangan mengenai apa yang seharusnya dilakukan dan tidak dilakukan. Guna mencapai tujuan dimaksud, maka analisis data akan dimulai dengan telaah terhadap beberapa aturan, norma, dan asas hukum terkait dengan tema penelitian. Kesemuanya akan diinventarisir dan dianalisis dengan menggunakan penafsiran hukum teleologis dan ekstensif.

\footnotetext{
2 Peter Mahmud Marzuki, 2005, Penelitian Hukum, Jakarta: Kencana, hlm. 141.
} 


\section{Hasil dan Pembahasan}

\subsection{Tinjauan Umum Mengenai Hukum Hak Asuh Anak}

Dalam konsepsi hak asuh anak, khususnya di Indonesia, secara umum dapat dikemukakan bahwa konstruksi hukum hak asuh anak terbagi ke dalam dua patron hukum, yaitu hak asuh (hadhanah) dalam hukum keluarga Islam dan hak asuh anak dalam hukum keluarga (hukum positif) di Indonesia.

\subsubsection{Hak Asuh Anak (Hadlanah) dalam Hukum Keluarga Islam (Al Ahwal Al Syaksiyah)}

Dalam hukum keluarga Islam, Pengasuhan (hadlanah) menempati satu dari beberapa konsep perwalian yang pengaturannya sangat jelas. Pegaturan ini membentang dan melingkupi ihwal sejak seorang anak dalam kandungan ibunya. Sejak dalam kandungan sekalipun, seorang anak telah memiliki apa yang disebut dengan ahliyah wujub naqishah yaitu kepantasan untuk memiliki hak-hak ${ }^{3}$.

Dalam konteks inilah penyelesaian sengketa hak asuh anak tidak hanya terkait siapa yang berhak mengasuh si anak, namun juga bagaimana hak-hak dan kepentingan terbaik anak dapat terjamin oleh pemegang hak asuhnya ${ }^{4}$. Pengasuhan anak dalam hukum Islam dapat dikatakan menjangkau hal-hal dari sejak anak dlaam kandungan hingga ia lahir ke dunia. Daya jangkau ini menunjukkan bahwa hukum Islam menyadari benar arti penting dari kedudukan anak dalam keluarga serta perlunya tata laksana pengasuhan anak agar kelak ia dapat tumbuh kembang dengan baik serta berperan penting dalam pengembangan syiar agama serta pembangunan bangsa dan negara. Anak, dalam tata pikir demikian, merupakan aset bangsa yang harus dijaga sedemikian rupa agar kelak ia dapat berkontribusi positif bagi lingkungan sosialnya.

Untuk mendefinisikan pengasuhan anak (hadhanah) menurut hukum Islam, perlu terlebih dahulu mengetahui arti harfiah dari kata hadhanah tersebut. Hadlanah merupakan kata dalam bahasa Arab yang berakar pada kata "al hidln" yang berarti "rusuk"5, "al janb" yang berarti "di samping atau berada di bawah ketiak" ${ }^{6}$. Kata hadlanah selanjutnya jamak digunakan dalam istilah hukum keluarga yang secara etimologis berarti "pengasuhan anak". Dalam sejarahnya, seorang ibu yang mengasuh anak umumnya menggendong atau mengasuh anaknya dengan meletakkan si anak pada sebelah atau salah satu rusuknya, atau juga meletakkan si anak dalam pangkuannya ${ }^{7}$.

\footnotetext{
${ }^{3}$ Andi Syamsu Alam dan M. Fauzan, Hukum Pengangkatan Anak Perspektif Islam, Jakarta: Pena Media, 2008, hlm. 113.

${ }^{4}$ Tim Penyusun Pengadilan Agama Banjarbaru, Kontekstualisasi Hukum Perdata Islam, Yogyakarta: Phoenix, 2018, hlm. 1.

${ }^{5}$ Kamal Muchtar, Asas-Asas Hukum Islam tentang Perkawinan, Jakarta: Bulan Bintang, 2004, hlm. 137

${ }^{6}$ Satria Efendi M. Zein, Problematika Hukum Keluarga Islam Kontemporer, Jakarta: Kencana, 2004, hlm. 166.

${ }^{7}$ Kamal Muchtar, Loc. cit.
} 
Sementara itu, Amir Syarifuddin ${ }^{8}$ menyatakan bahwa hadlanah dalam pengertian sederhana adalah "pemeliharaan" atau "pengasuhan". Dalam pengertian yang lebih luas, hadlanah adalah pemeliharaan anak yang masih di bawah umur yang ditetapkan setelah terjadinya perceraian antara suami dan isteri. Penetapan hak pengasuhan anak pasca perceraian merupakan hal mendasar karena hak-hak anak perlu dilindungi setelah kedua orang tuanya bercerai.

Muhammad Husain Zahabi mendefinisikan hadlanah sebagai upaya melayani kebutuhan dan kepentingan anak yang masih di bawah umur oleh pihak-pihak yang diberi hak untuk melakukan hal tersebut. Melayani kebutuhan anak tidak terbatas pada pemenuhan hak-hak dasarnya semata, namun juga mencakup upaya mendidik kepribadian dan mentalitas anak ${ }^{9}$.

Pada definisi lain yang memiliki pemaknaan serupa, Andi Syamsu Alam dan Ahmad Fauzan ${ }^{10}$ mendefinisikan hadlanah sebagai kewenangan yang diberikan kepada pihak tertentu guna melaksanakan tugas merawat dan mendidik anak yang masih belum mumayyiz (dewasa). Pemasalahan hadlanah dapat muncul dikarenakan adanya perceraian dari kedua orang tua si anak atau karena kedua orang tua anak tersebut meninggal dunia. Pentingnya menetapkan pihak yang berhak melakukan tugas dan fungsi hadlanah dilatari kenyataan bahwa si anak yang belum mumayyiz secara faktual belum dapat memenuhi kebutuhannya sendiri serta belum dapat mengorganisasikan kehidupannya selayaknya orang-orang yang telah dewasa.

Dari beberapa pendapat tersebut, dapat disimpulkan bahwa hadlanah merupakan penetapan yang memberikan kewenangan kepada salah satu pihak untuk melaksanakan tugas dan kewajiban mengurus dan memenuhi kebutuhan seorang anak yang belum mumayyiz, baik secara moril maupun materil, guna menjamin terpenuhinya hak-hak dasar anak hingga anak tersebut dewasa dan/atau mandiri. Dalam hadlanah terkandung suatu prinsip bahwa yang menjadi aksentuasi hadlanah adalah kepentingan terbaik si anak, yaitu bagaimana hadlanah mampu menjamin terpenuhinya hak-hak dasar si anak dan memastikan bahwa hadlanah dapat menghindarkan si anak dari berbagai kemudharatan yang mungkin dapat menimpanya.

Dalam QS. Al Baqarah ayat 233 disyariatkan kewajiban mengasuh anak dengan sebaik-baiknya. Firman Allah SWT, yang artinya: "Para ibu hendaklah menyusukan anak-anaknya selama dua tahun penuh, Yaitu bagi yang ingin menyempurnakan penyusuan dan kewajiban ayah memberi makan dan pakaian kepada para ibu dengan cara ma'ruf. Seseorang tidak dibebani melainkan menurut kadar kesanggupannya. Janganlah seorang ibu menderita kesengsaraan karena anaknya dan seorang ayah karena anaknya, dan warispun berkewajiban demikian. Apabila keduanya ingin menyapih (sebelum dua tahun) dengan kerelaan keduanya dan permusyawaratan, maka tidak ada dosa atas keduanya, dan jika kamu ingin anakmu

\footnotetext{
${ }^{8}$ Amir Syarifuddin, Hukum Perkawinan Islam di Indonesia: Antara Figh Munakahat dan UndangUndang Perkawinan, Jakarta: Kencana, 2007, hlm. $327-328$.

${ }^{9}$ Andi Syamsu Alam dan M. Fauzan, Op.Cit, hlm. 114.

${ }^{10}$ Ibid.
} 
disusukan oleh orang lain, maka tidak ada dosa bagimu apabila kamu memberikan pembayaran menurut yang patut. Bertakwalah kamu kepada Allah dan ketahuilah bahwa Allah Maha melihat apa yang kamu kerjakan"'"

Secara tersirat, ayat ini mewajibkan bagi kedua orang tua untuk mengasuh anaknya dengan baik. Dalam hal terjadi perceraian, kewajiban tersebut tetap melekat. Permasalahannya hanya pada tidak adanya penegasan mengenai siapa yang lebih berhak mengasuh anak pasca perceraian serta urutan pihak yang lebih berhak atas pengasuhan anak.

Terkait dengan hal tersebut, jumhur ulama berpendapat bahwa pengasuhan anak pasca terjadinya perceraian kedua orang tua diutamakan kepada ibu kandungnya. Pendapat ini didasarkan pada pertimbangan bahwa seorang ibu cenderung (pada umumnya) mengasuh anak dengan lebih baik dibanding ayahnya. Naluri kasih sayang seorang ibu pada umumnya jauh lebih kuat, demikian pula dengan kedekatan emosionalnya ${ }^{11}$.

Pada masa-masa awal Rasulullah SAW, kecenderungan yang ada - kalau tidak mengatakan secara keseluruhan - para ibu (perempuan) lebih sering berada dan menghabiskan waktu di rumah sementara para ayah (laki-laki) lebih sering berada di luar rumah untuk mencari nafkah dan/atau melakukan aktivitas lainnya. Keadaan ini secara subjektif melahirkan suatu asumsi dasar bahwa ibu (perempuan) memiliki waktu bersama (quality time) yang lebih banyak dalam mengasuh anak, dengannya para ibu lebih memahami keadaan dan kebutuhan faktual anaknya.

Sifat-sifat dan keadaan para ibu (perempuan) sebagai dikemukakan tersebut sangat diperlukan dalam pengasuhan anak ${ }^{12}$. Ada korelasi yang signifikan antara banyaknya waktu yang dihabiskan bersama anak dengan kualitas pengasuhan yang dilakukan. Dalam kaitan dengan hal ini, Rasulullah SAW pernah menyelesaikan suatu perselisihan antara ayah dan ibu mengenai siapa yang berhak mengasuhnya. Peristiwa tersebut disebutkan dalam hadits yang diriwayatkan oleh Abu Daud dan Ahmad dengan disahkan oleh Al Hakim:

"Dari Abdullah bin 'Amar bahwasanya seorang wanita berkata: 'Ya Rasulullah, bahwasanya anakku ini perutkulah yang mengandungnya, asuhankulah yang mengawasinya, dan air susukulah minumannya, bapaknya hendak mengambilnya dari padaku'. Maka berkata Rasulullah: 'Engkau lebih berhak atasnya (anak itu) selama engkau belum menikah (dengan laki-laki yang lain)"13

Ketentuan dalam hadits tersebut melahirkan kaidah hukum bahwa keutamaan seorang ibu untuk mengasuh anaknya ditentukan oleh dua persyaratan, yaitu 1) ibu kandung belum menikah lagi dengan laki-laki lain; dan 2) ibu kandung memenuhi syarat-syarat untuk mengasuh anak. Jika salah satu atau kedua syarat tersebut tidak dipenuhi, maka kedudukan ibu kandung untuk mengasuh anak tidak lebih utama

\footnotetext{
${ }^{11}$ Kamal Muchtar, Op.Cit., hlm. 140.

12 Ibid.

${ }^{13}$ Amir Syarifuddin, Op.Cit, hlm. 329 - 330.; Kamal Muchtar, Ibid.
} 
dibandingkan ayah si anak. Dalam keadaan demikian, hak pengasuhan (dapat) berpindah kepada urutan yang paling dekat, yaitu ayah ${ }^{14}$.

Dalam salah satu riwayat pada kitab al Muwaththa, disebutkan bahwa Umar bin Khaththab menikah dengan seorang perempuan dari golongan Anshar. Dari perkawinan tersebut lahir seorang anak bernama Ashim bin Umar. Dalam perjalanan rumah tangganya, Umar bin Khaththab bercerai dengan isterinya tersebut. Pada suatu ketika, Umar melakukan perjalanan ke Quba' dan menemui anaknya sedang bermain di dalam masjid. Setelahnya, Umar mengambil anak tersebut dan menaikkanny ke kuda. Melihat hal itu, nenek si anak mengatakan itu anakku, demikian pula dengan Umar. Terjadilah perselisihan di antara mereka mengenai siapa yang lebih berhak mengasuh anak tersebut. Setelah dihadapkan kepada Abu Bakar, Abu Bakar memutuskan bahwa anak tersebut ikut (diasuh) oleh ibunya ${ }^{15}$.

Salah satu dasar pertimbangan Abu Bakar dalam menetapkan pengasuhan anak kepada ibunya adalah kecenderungan umum seorang ibu (perempuan) yang memiliki perasaan lebih halus, pemurah (hati), berkarakter penyantun, dan lebih menyayangi anaknya. Penekanannya adalah hak tersebut dibatasi oleh keadaan dimana si ibu belum menikah lagi dengan laki-laki lain ${ }^{16}$. Bukan berarti laki-laki tidak memiliki sifat-sifat tersebut, namun oleh karena secara umum laki-laki identik dengan maskulinitas yang berbeda secara diametral dengan karakteristik feminim tersebut, maka cukup beralasan untuk menyatakan bahwa secara umum perempuan lebih lemah lembut, lebih penyayang, dan bermurah hati (mudah tergerak hatinya untuk menolong).

Dalam hukum keluarga Islam, ketentuan mengenai hadhanah diatur secara cukup terperinci. Beberapa pengaturan mengenai hadhanah di antaranya adalah sebagai berikut:

\section{Rukun hadhanah}

Ada dua rukun dalah pengasuhan (hadhanah), yaitu pengasuh (hadhin) dan yang diasuh (mahdhun) ${ }^{17}$.

a. Pengasuh (hadhin)

Pengasuh (hadhin) adalah pihak yang ditetapkan (oleh Pengadilan) untuk menjalankan tugas dan kewajiban memelihara dan mengasuh seorang anak yang belum mumayyiz. Pengasuh umumnya dianjurkan dari pihak keluarga ibu si anak. Setelahnya baru ke pihak keluarga ayah si anak. Namun

\footnotetext{
${ }^{14}$ Amir Syarifuddin, Ibid, hlm. 330.

${ }^{15}$ Kamal Muchtar, Ibid, hlm. 141.

${ }^{16}$ Ibid. Terdapat hal-hal yang memang secara kodrat melekat pada diri perempuan, antara lain perasaan yang lebih halus dan peka terhadap hal-hal yang sifatnya sensitif. Sekalipun bukan keadaan yang sifatnya mutlak, namun tidak dapat dinafikan pula bahwa pada umumnya sifat-sifat yang dikemukakan oleh Abu Bakar tersebut melekat dan menjadi jati diri seorang perempuan.

${ }^{17}$ Amir Syarifuddin, Op.Cit, hlm. 328.; Andi Syamsu Alam dan Ahmad Fauzan, Op.Cit, hlm. 121 - 122.; Kamal Muchtar, Op.Cit., hlm. $143-144$.
} 
demikian, ketentuan ini masih bersifat ijtihadiy, dalam arti bahwa jika ada situasi yang mendesak, pihak keluarga si ayah dapat lebih didahulukan.

b. Anak yang diasuh (mahdhun)

Mahdhun adalah anak yang memerlukan pengasuhan oleh pihak tertentu akibat perceraian kedua orang tuanya atau karena kedua orang tuanya meninggal dan pada saat yang sama si anak yang belum mumayyiz belum dapat memenuhi sendiri kebutuhan-kebutuhan hidupnya. Ukuran mumayyiz anak berbeda-beda karena ulama memiliki pandangan berbeda mengenai hal ini. Sebagai sebuah patokan, ukuran anak mumayyiz, dapat memedomani ketentuan dalam KHI Pasal 105 huruf (a) yang menetapkan umur anak yang belum mumayyiz adalah yang belum genap 12 tahun.

\section{Syarat bagi pemegang hadhanah}

Hal yang paling mendasar dalam hadhanah adalah penentuan syarat-syarat bagi pemegang hadhanah. Hal ini dikarenakan pemegang hadhanah haruslah orang yang diperkirakan dapat mengaush anak dengan baik dan amanah. Tanpa adanya minimal dua hal tersebut maka suliat untuk mewujudkan hadhanah yang menjamin kelangsungan dan keterpenuhan hak-hak dasar anak.

Dari sejumlah literatur, dapat dipaparkan beberapa persyaratan yang harus dipenuhi bagi seseorang untuk ditetapkan menjadi pemegang hadhanah atau hadhin. Sebagaimana dirangkum oleh Amir Syarifuddin ${ }^{18}$, berikut dipaparkan persyaratan seseorang dapat ditetapkan sebagai pemegang hadhanah:

a. Dewasa

Syarat pertama dan utama bagi seorang hadhin adalah ia harus dewasa. Dewasa adalah keadaan seseorang yang memenuhi syarat-syarat atau ketentuan menurut hukum seperti telah berusia di atas 21 tahun, mandiri, mampu memenuhi kebutuhan hidupnya sendiri, cakap melakukan tindakan hukum (rechtsbekwaamheid), berwenang melakukan tindakan hukum tertentu (rechtsbevoegheid), serta ia tidak berada di bawah pengampuan, dan memiliki integritas yang baik. Tegasnya, dewasa adalah keadaan objektif pada diri seseorang yang membuat ia cakap bertindak hukum untuk kepentingan hukum tertentu, khususnya demi kepentingan terbaik si anak.

b. Berakal sehat

Berakal sehat adalah kemampuan seseorang dalam mengorganisasikan pikiran-pikirannya, mampu menyinergikan pikiran, perasaan, dan perilakunya, mampu berpikir logis, mampu mengenali keadaan lingkungan sekitarnya, dan tidak mengalami ganggungan psikologis tertentu. Berakal sehat mampu membedakan dengan baik hal-hal yang sesuai dan bertentangan dengan norma. Dalam konteks hadhanah, seseorang yang

${ }^{18}$ Amir Syarifuddin, Ibid, hlm. 328 - 329. 
berakal sehat mampu memilah, memilih, dan melaksanakan tindakantindakan yang dianggap terbaik bagi kepentingan si anak.

c. Cakap dalam merawat anak

Pengasuh wajib memiliki kemampuan merawat (mengasuh) anak dengan baik. Kemampuan tersebut tergambar dari visinya dalam penatalaksanaan pengasuhan anak, antara lain kemampuannya mengidentifikasi kebutuhan dasar anak, tindakan-tindakan preventif yang diperlukan guna menghindarkan anak dari ke-mudharat-an, upaya meningkatkan kualitas hidup anak, membangun pola komunikasi dengan anak yang konstruktif, serta perencanaan atas pendidikan anak demi kepentingannya pada masa yang akan datang.

d. Beragama Islam

Terdapat perbedaan pendapat mengenai syarat beragama Islam bagi hadhin. Jumhur ulama berpendapat bahwa salah satu syarat yang wajib dipenuhi oleh hadhin adalah ia harus beragama Islam. Dasar pemikirannya adalah bahwa tugas pengasuhan tidak hanya terkait dengan pemenuhan kebutuhan fisik si anak, namun juga bersentuhan langsung dengan salah satu tujuan syariat Islam, yaitu hifz al din (menjaga agama atau keyakinan). Jika seorang anak muslim diasuh oleh orang yang tidak beragama Islam, dikhawatirkan hal tersebut akan mengganggu akidah anak karena besar kemungkinan pengasuh non muslim berupaya memengaruhi akidah si anak untuk mengikuti akidah pengasuhnya.

Tiga madzhab dalam figh yaitu Syafi'iyah, Hanabilah, dan Hanafiyah cenderung mensyaratkan Islam sebagai prasayarat yang harus ada bagi pemegang hak asuh anak. Madzhab Hanafiyah secara khusus menekankan prasayarat "Islam" pada pihak laki-laki sementara bagi kalangan perempuan tidak dipersyaratkan demikian. Madzhab Malikiyah secara umum tidak mensyaratkan "Islam" sebagai syarat bagi pemegang hak asuh bagi anak muslim. Namun demikian, penganut Malikiyah menekankan harus adanya kepastian atau upaya memastikan bahwa si anak diberi makanan yang tidak mengandung bahan-bahan atau unsur-unsur yang diharamkan oleh Islam seperti khamr, babi, atau substrat lain yang tidak sejalan dengan syariat Islam. Dalam keadaan dimana ada kecenderungan si anak diberi makanan tersebut, maka hak pengasuhan anak diberikan kepada pihak laki-laki. ${ }^{19}$

Secara prinsip, orang non muslim tidak memiliki kewenangan mengasuh anak muslim, demikian secara singkat pandangan madzhab Syafiiyah dan Hanabilah. Orang non muslim secara syara' tidak berwenang memimpin kaum muslimin. Jika pada kenyataannya tidak ada orang muslim, maka pengasuhan dapat beralih kepada non muslim yang dikatagorikan sebagai kafir zimmi, yaitu non muslim yang tidak memusuhi Islam secara terang-

\footnotetext{
${ }^{19}$ Erfani Aljan Abdullah, Pembaruan Hukum Perdata Islam: Praktik dan Gagasan, Yogyakarta: UII
} Press, 2017, hlm. $110-111$. 
terangan. Madzhab Malikiyah dan Madzhab Hanafiyah, menurut Andi Syamsu Alam dan M. Fauzan tidak mensyaratkan Islam bagi pengasuh anak muslim. Hal ini didasarkan pada salah satu hadits Nabi Muhammad SAW yang diriwayatkan oleh Abu Dawud: "Ya Allah, tunjuki anak itu, condongkan hatinya kepada ayahnya". Dalam hadits tersebut, Rasulullah SAW diperhadapkan pada suatu kasus perebutan hak asuh anak dan Rasulullah memerintahkan kepada si anak memilih di antara ayah (muslim) dan ibunya (non muslim) yang pada akhirnya si anak memilih ibunya yang non muslim. Rasulullah kemudian berdoa seperti redaksi tersebut ${ }^{20}$.

e. Adil

Seseorang yang akan ditetapkan sebagai hadhin harus memiliki sifat adil. Adil dalam hal ini bermakna bahwa pengasuh anak (hadhin) menjalankan syariat Islam dengan baik, antara lain melaksanakan ibadah dengan baik dan rutin, menjauhi sifat-sifat dan perbuatan tercela yang dilarang agama. Pengasuh memiliki integritas yang baik, dalam arti mampu menjaga amanah dengan sebaik-baiknya. Dalam pengertian lebih jauh, pengasuh merupakan pribadi yang taat pada hukum; menghindarkan dirinya dari perbuatanperbuatan melawan hukum. Indikasi-indikasi seseorang adil atau tidak dapat terlihat dari bagaimana relasi sosialnya yang baik dan konstruktif dalam kehidupan bermasyarakat.

Untuk mengetahui seseorang dapat berlaku adil atau tidak, misalnya, dapat dilihat dari bagaimana ia berperilaku sehari-hari. Seseorang yang "adil" dapat tergambar dari bagaimana ia memberi perhatian dan memegang prinsip-prinsip kebenaran, baik terhadap orang lain maupun terhadap dirinya sendiri. Jika seseorang dapat memperlakukan orang lain sebagaimana mestinya, ia terindikasi kuat dapat berlaku adil, termasuk dalam konteks ia sebagai pemegang hadhanah.

\subsubsection{Norma Hukum Hak Asuh Anak dalam Hukum Keluarga Indonesia}

Dalam perundang-undangan, setidaknya ada dua peraturan utama yang mengatur perihal hak asuh anak. Pertama, Undang-Undang Nomor 1 Tahun 1974 tentang Perkawinan (UUP). UUP menegaskan beberapa norma tentang kedudukan anak dan pengasuhannya, khususnya pada Bab X dan Bab XI. Kedua, Kompilasi Hukum Islam, khususnya pada Bab XIV dan Bab XV.

UUP mengatur beberapa hal mengenai kedudukan anak dan pemeliharaannya, baik ia dalam kekuasaan orang tua maupun dalam kekuasaan wali. UUP memang tidak secara khusus menegaskan norma spesifik mengenai pengasuhan anak (siapa yang berhak mengasuh), namun dalam pengaturannya, terdapat beberapa prinsip dalam mengasuh dan mendidik anak yang berada di bawah kekuasaan orang tua/wali, sebagai berikut:

\footnotetext{
${ }^{20}$ Andi Syamsu Alam dan M. Fauzan, Op.Cit, hlm. 122.
} 
a. Orangtua anak (ayah dan ibu kandung) wajib memelihara dan mendidik anakanaknya dengan sebaik-baiknya. Pemeliharaan di sini termasuk pula memenuhi kebutuhan primer dan pendukung lainnya bagi tumbuh kembang si anak menurut kemampuan kedua orangtuanya;

b. Kewajiban memelihara dan mendidik anak berlangsung dari sejak si anak lahir hingga anak tersebut dewasa dan/atau mandiri. Norma ini menegaskan pula bahwa jikapun terjadi perceraian antara ayah dan ibu si anak, keduanya tetap memikul kewajiban tersebut;

c. Yang dikatagorikan sebagai anak adalah mereka yang belum berumur 18 tahun. Sebelum mencapai usia 18 tahun, maka si anak, secara hukum, berada di bawah kekuasaan kedua orangtuanya atau wali yang ditetapkan oleh Pengadilan;

d. Orangtua dapat dicabut kekuasaannya terhadap anaknya jika: i) ia melalaikan kewajiban terhadap anaknya; dan/atau ii) memiliki perilaku buruk yang dapat merugikan anaknya;

e. Jikapun seorang orangtua dicabut kekuasaannya oleh Pengadilan, ia tetap berkewajiban untuk menafkahi anaknya tersebut;

f. Tanggung jawab dan kekuasaan orangtua/wali terhadap anak mencakup diri dan harta si anak serta berwenang mewakili anak melakukan perbuatan hukum di dalam maupun di luar Pengadilan. Sedemikian besar kewenangan dan tanggung jawab tersebut, sehingga orangtua atau wali wajib menjaga amanah dan memastikan bahwa tindak lakunya benar-benar demi kepentingan terbaik si anak.

Sementara itu, dalam Kompilasi Hukum Islam, pengaturan mengenai hak asuh anak lebih terperinci. Secara umum, dapat diabstraksikan beberapa prinsip maupun norma hukum hak asuh anak (hadhanah) sebagai berikut:

a. Pemeliharaan anak (hadhanah) bagi anak yang belum berumur 12 tahun menjadi hak ibu kandungnya, kecuali ditentukan lain berdasar putusan Pengadilan;

b. Bagi anak yang telah berumur di atas 12 tahun (mumayyiz), anak tersebut berhak memilih dengan siapa dia hidup atau bertempat tinggal (dapat menentukan sendiri hadhin-nya);

c. Ayah kandung anak berkewajiban memenuhi nafkah hidup si anak sekalipun hadhin si anak tidak ditetapkan kepada ayah kandungnya;

d. Setiap orang tua, baik ayah maupun ibu kandung, wajib memelihara dan mendidik anak-anaknya dengan sebaik-baik pemeliharaan;

e. Terhadap diri dan harta anak, kedua orang tua berkewajiban menjaga dan mengelolanya untuk kepentingan terbaik bagi si anak;

f. Ayah dan ibu atau salah seorang di antara mereka yang ditetapkan sebagai hadhin wajib memiliki sifat amanah dan adil agar terwujud jaminan pemeliharaan terbaik bagi si anak. 


\subsection{Perkembangan Pemikiran dalam Praksis Penyelesaian Sengketa Hak Asuh Anak}

Telah diketahui dari paparan sebelumnya bahwa norma umum penentuan hak asuh anak merujuk pada ketentuan UUP dan KHI Pasal 105. Dari kedua aturan tersebut, maka hak asuh anak yang belum mumayyiz menjadi hak atau ditetapkan kepada ibunya. Artinya bahwa, jika tidak terdapat indikasi atau keadaan-keadaan yang terindikasi merugikan kepentingan anak, maka hak asuh anak hampir pasti menjadi hak atau ditetapkan kepada ibu kandung si anak.

Dalam perkembangannya, terjadi pergeseran pemikiran mengenai penentuan hak asuh anak. Pergeseran pemikiran ini dipengaruhi oleh beberapa yurisprudensi tentang hak asuh anak yang melahirkan kaidah hukum baru penentuan hak asuh anak. Selain itu, perkembangan pemikiran mengenai pengasuhan anak pada beberapa negara common law turut memengaruhi pembentukan dan pembaruan norma hukum hak asuh anak.

\subsubsection{Yurisprudensi Mengenai Hak Asuh Anak}

Salah satu yurisprudensi yang mengubah "pakem" penentuan hak asuh anak selama ini adalah Putusan Mahkamah Agung Nomor 110 K/AG/2007 tanggal 13 November 2007. Sebelum adanya yurisprudensi tersebut, secara umum penentuan hak asuh anak merujuk pada ketentuan Pasal 105 huruf (a) KHI an sich. Artinya, bahwa terlepas dari keadaan-keadaan (special circumstances) yang tidak mendukung penerapan norma an sich, putusan-putusan hak asuh anak tetap menentukan hak asuh kepada ibu kandungnya.

Yurisprudensi Nomor $110 \mathrm{~K} / \mathrm{AG} / 2007$ mengubah norma umum penentuan hak asuh anak dari yang sebelumnya sangat normatif menjadi lebih komprehensif dan didasarkan pada kepentingan terbaik si anak. Yurisprudensi ini lahir di tengah maish dominannya paradigma positivistik penentuan hak asuh anak alih-alih upaya memutus hak asuh anak menurut kepentingan terbaik si anak.

Pada perkara dimaksud, Mahkamah Agung menetapkan hak asuh anak jatuh ke ayah kandung si anak (Tergugat Asal/Pemohon Kasasi) dengan pertimbangan kemashlahatan si anak. Secara lengkap, Mahkamah Agung dalam pertimbangannya menyatakan:

"Bahwa mengenai pemeliharaan anak bukan semata-mata dilihat dari siapa yang paling berhak, akan tetapi melihat fakta ikut siapa yang lebih mendatangkan kerusakan bagi si anak, dengan kata lain yang harus lebih dikedepankan adalah kepentingan si anak, bukan siapa yang paling berhak. Dan fakta yang telah diungkapkan Hakim Pertama, si anak akan lebih menderita sekiranya ia harus ikut ibunya, karena ibu si anak sering bepergian ke luar negeri dan tidak jelas si anak harus bersama siapa, sedangkan fakta yang ada sekarang si anak tenang dan tenteram bersama bapaknya (Pemohon Kasasi). Bahwa sekalipun anak yang bernama Kiara Andjani Rachman ditetapkan di bawah hadhanah Pemohon Kasasi/Tergugat" 
Sebelumnya, Mahkamah Agung telah mengukuhkan penerapan norma hukum hak asuh anak "berdasar kepentingan terbaik si anak" melalui Putusan Nomor 267 K/AG/2006 tanggal 28 Februari 2007. Putusan ini mengukuhkan putusan judex factie Pengadilan Agama Cibinong melalui (Putusan Nomor 777/Pdt.G/2003/PA.Cbn. tanggal 19 April 2004) dan Pengadilan Tinggi Agama Bandung (Putusan Nomor 170/Pdt.G/2004/PTA.Bdg. tanggal 27 Oktober 2005).

Dari putusan tersebut, Mahkamah Agung dalam pertimbangannya menyatakan bahwa penentuan pemegang hak asuh anak harus memerhatikan kepentingan terbaik anak. Pemohon (ayah si anak) dalam perkara tersebut dipandang lebih cakap dan lebih mampu menjamin kepentingan dan kemashlahatan anaknya, karenanya ia ditetapkan sebagai pemegang hak asuh anak. Ini juga sekaligus menyimpangi secara diametris teks Pasal 105 Kompilasi Hukum Islam yang menegaskan bahwa anak yang belum berumur 12 tahun berada di bawah pengasuhan ibu kandungnya.

Pembaruan norma hukum hak asuh anak dalam yurisprudensi tersebut di atas menandai dimulainya penentuan hak asuh anak dengan dasar utama kepentingan terbaik bagi anak. Paradigma yang muncul kemudian adalah bahwa penentuan hak asuh anak tidak lagi semata-mata melihat keadaan dari kedua orang tuanya, namun lebih dari itu harus memerhatikan dengan seksama keadaan si anak dan bagaimana hubungan atau relasi yang terbangun antara si anak dengan kedua orang tuanya. Penting pula memerhatikan faktor kenyamanan dan kemampuan anak mengekspresikan diri dan pikirannya jika ia sedang bersama dengan salah seorang dari orang tuanya.

\subsubsection{Pengasuhan Anak Secara Bersama (Shared Parenting Responsibility)}

Pada perkembangannya, norma dan konsepsi pengasuhan anak tidak lagi sekadar berkutat pada pengasuhan terpisah (split parenting), namun mulai mengarah pada konsepsi pengasuhan bersama (shared parenting). Ada beberapa alasan mengapa pengasuhan bersama kemudian mendapat perhatian cukup besar dalam penormaan hak asuh anak. Dikemukakan oleh Mason:

"the 'best interests of the child' standard has historically reflected a struggle between mothers' and fathers' rights, with children's needs considered to be commensurate with either position. Children are viewed at different times as fathers' property, as requiring the 'tender care' of mothers, and as rightfully 'belonging' to one or the other parent" 21

Dari paparan Mason, tergambar bahwa pengasuhan anak seharusnya lebih memerhatikan kepentingan terbaik bagi si anak. Kepentingan anak menjadi dasar atau preferensi utama dalam tata laksana pengasuhan. Karenanya, harus dieliminir pandangan-pandangan yang cenderung menganggap atau menempatkan anak sebagai "milik ayahnya", atau "milik ibunya", atau "sebagai objek hak" dari salah satu dari orangtuanya.

\footnotetext{
${ }^{21}$ Edward Kruk, Child Custody, Access and Parental Responsibility: The Search for A Just and Equitable Standard, The University of British Columbia, 2008, hlm. i.
} 
Karenanya, Edward Kruk, dalam penelitiannya menyimpulkan:

"The most recent research strongly supports a shift away from the 'one size fits all', 'winner take all' sole custody framework toward the notion of shared parental responsibility" 22

Pengasuhan anak menurut Kruk yang selama ini berkutat pada split parenting atau sole custody berimplikasi pada adanya asumsi bahwa pemegang hak asuh berhak sepenuhnya terhadap kehidupan anaknya (winner takes all). Ini melahirkan kebiasaan pemegang hak asuh berhak mengatur secara ketat pertemuan anak dengan orangtua lain yang tidak memegang hak asuh.

Model atau pradigma demikian tidak selaras dengan upaya memberi keleluasaan bagi anak untuk mengekspresikan dirinya, bersosialisasi dengan kedua orangtuanya secara masif, dan memeroleh kasih sayang terbaik dari kedua orangtuanya. Sebaliknya, anak seolah terkungkung oleh kekuasaan pemegang hak asuh terhadapnya, diwajibkan tunduk pada aturan-aturan tak tertulis yang dibuat oleh pemegang hak asuhnya.

Konsepsi pengasuhan bersama menawarkan paradigma baru dalam tata laksana pengasuhan anak. Konsepsi ini telah jamak diimplementasikan di negara-negara common law seperti Amerika Serikat dan Kanada.

Di Kanada misalnya, pengasuhan bersama diatur dalam undang-undang perceraian Kanada (1997 Federal Child Support Guidelines under the Divorce Act), shared custody (pengasuhan bersama) adalah pengaturan mengenai waktu bersama antara anak dengan masing-masing orang tuanya. Alokasi waktu yang ditetapkan dalam pengasuhan bersama antara anak dengan kedua orang tuanya adalah minimal $40 \%$ waktu pengasuhan bagi masing-masing orang tua ${ }^{23}$.

Jika dikaitkan kembali antara konsepsi pengasuhan anak bersama (shared parenting) dengan nash-nash syara' dan ketentuan dalam hukum perkawinan Indonesia (termasuk yurisprudensi mengenai hak asuh anak), dapat diketahui bahwa normanorma tersebut bersandar pada upaya luhur untuk menjamin kepentingan terbaik bagi si anak. Pengasuhan anak, sejatinya, bukan hanya berkutat pada siapa mengasuh siapa. Namun, lebih dari itu, penentuan pengasuhan anak diarahkan agar semaksimal mungkin memberi kebaikan, kemanfaatan, dan jaminan akan masa depan anak yang lebih baik.

Pada konteks ini, konsepsi pengasuhan bersama sangat concern dengan upaya-upaya dimaksud. Dengan lain perkataan bahwa, pengasuhan bersama menekankan upaya yang dinamis dari kedua orangtua si anak untuk bersama-sama mendidik, memelihara, dan memastikan tumbuh kembang anak sesuai harkat dan martabatnya.

\footnotetext{
22 Ibid, hlm. li.

${ }^{23}$ Sharon Moyer, Child Custody Arrangements: Their Characteristics and Outcomes, Makalah, 2004, hlm. 3
} 
Bagaimanapun, seorang anak, sejatinya memerlukan kasih sayang dan perhatian yang utuh dari kedua orangtuanya. Jika si anak belajar tentang kasih sayang, rasa cinta, kelemahlembutan, dan perhatian (empati) dari ibunya, maka si anak belajar tentang keteguhan hati, konsistensi, kekuatan diri, dan ketangguhan dalam menghadapi cobaan hidup dari ayahnya.

Pengasuhan bersama memerhatikan benar hal-hal tersebut di atas. Sembari memberi kebebasan ruang gerak bagi si anak dalam mengekspresikan dirinya, konsepsi ini juga memberi porsi signifikan bagi kedua orangtua dalam mengambil peran aktif mendidik dan memastikan masa depan yang lebih baik bagi anakanaknya.

\section{Penutup}

Dari uraian-uraian tersebut di atas, disimpulkan beberapa hal sebagai berikut:

a. Hukum hak asuh anak di Indonesia, dari sisi normatif dan praktik, secara umum masih menerapkan model pengasuhan terpisah atau pengasuhan oleh salah seorang orangtua anak (split parenting, split custody);

b. Patronase penentuan hak asuh dalam penyelesaian sengketa hak asuh anak ada dua. Pertama, patronase normatif dengan mengacu pada ketentuan Pasal 105 Kompilasi Hukum Islam. Kedua, patronase kepentingan terbaik anak berdasar Yurisprudensi Mahkamah Agung;

c. Pengasuhan bersama (shared parenting) merupakan gagasan yang ingin menengahi perbedaan kedua model dan patron tersebut serta menawarkan suatu konsep pengasuhan yang tidak hanya berfokus pada perwujudan kepentingan terbaik si anak, namun juga mengupayakan peran maksimal kedua orangtua dalam mengasuh anak-anaknya.

\section{DAFTAR PUSTAKA}

Amir Syarifuddin, 2007, Hukum Perkawinan Islam di Indonesia: Antara Fiqh Munakahat dan Undang-Undang Perkawinan, Jakarta: Kencana.

Andi Syamsu Alam dan M. Fauzan, 2008, Hukum Pengangkatan Anak Perspektif Islam, Jakarta: Pena Media.

Edward Kruk, 2008, Child Custody, Access and Parental Responsibility: The Search for A Just and Equitable Standard, The University of British Columbia.

Erfani Aljan Abdullah, 2017, Pembaruan Hukum Perdata Islam: Praktik dan Gagasan, Yogyakarta: UII Press.

Kamal Muchtar, 2004, Asas-Asas Hukum Islam tentang Perkawinan, Jakarta: Bulan Bintang.

Satria Efendi M. Zein, 2004, Problematika Hukum Keluarga Islam Kontemporer, Jakarta: Kencana. 
AL-IQTISHADIYAH

Jurnal Ekonomi Syariah dan Hukum Ekonomi Syariah

Sharon Moyer, 2004, Child Custody Arrangements: Their Characteristics and Outcomes, Makalah.

Tim Penyusun Pengadilan Agama Banjarbaru, 2018, Kontekstualisasi Hukum Perdata Islam, Yogyakarta: Phoenix. 